\title{
Endangered
}

\section{When newspaper archives crumble, history dies}

\author{
GERRY VAN KLINKEN
}

\begin{abstract}
Historians accept the death of oral sources, but expect newspaper archives in state institutions to be available for ever. Yet the majority of Indonesian newspaper titles in the National Library are today endangered. These crumbling papers are often the only copy in the world. This article first reviews the role these archives have played in pathbreaking historical work, both Indonesian and foreign. Provincial newspapers record the chatter of a new, literate middle class that emerged in the middle of the tumultuous twentieth century. Indonesian historiography is transformed by the many surprises scholars experience when reading their lives there. When those sources turn to dust, historical research dies. This will affect not just specialized historians, but social scientists in many fields. The article then maps quantitatively the extent to which these papers are endangered. It finally urges the social science community as a whole to campaign to save them through comprehensive digitization.
\end{abstract}

KEYWORDS

Archives; newspapers; library; Jakarta; Indonesia; history; twentieth century; digitization; middle class; provincial towns.

"History is always written wrong, and so always needs to be rewritten" (Santayana 1905-06: Vol. 5, Ch. 2).

\section{INTRODUCTION}

Constant rewriting, the American philosopher George Santayana wrote, produces history that "truly informs or shapes the mind". This requires archives, and scholarly imagination. When either fails, history is once more reduced to legend. Historical reinterpretation experienced a rebirth in Indonesia once the deadening hand of the New Order was lifted. University

GERRY VAN KLINKEN is Honorary Professor of Southeast Asian history at the University of Amsterdam and at the University of Queensland. He recently retired from the KITLV/Royal Netherlands Institute of Southeast Asian and Caribbean Studies. He has published widely on Indonesian history, particularly on the rise of a provincial middle class. His fascination with Indonesia began as a lecturer in physics at various Indonesian and Malaysian universities in the 1980s. Gerry van Klinken may be contacted at: klinken@kitlv.nl. 
history departments are flourishing. Especially local histories are being written afresh in the era of local autonomy. The best work is stimulating new ways of thinking about the nation. However, while historical work no longer faces the peril of repression, a new threat is looming. It comes from an entirely different direction, and it is just as serious. The paper archives historians need are rapidly disintegrating. The threat is especially serious for archives dating to the tumultuous period between the 1930s and the 1970s. This is the period when Indonesia was transformed from a colonial society to a modern independent nation. Until recently, Indonesian historians could find enough witnesses to give them living access to most of that period. They believed in oral history almost as much as they trusted Dutch colonial "documents". But those oral witnesses have now mostly passed away. And Dutch archives contain a massive hole in the bulk of that period, since the two countries were divided by war. Indonesian-language newspapers are therefore among the most important repositories for that period. There is a supreme irony in the phenomenon of Indonesian researchers traveling all the way to the Netherlands for historical documents, when the really important documents are lying, almost unused and growing more fragile every year, right here in Jakarta.

The best collection lies at the National Library in Jakarta. It contains over a thousand newspaper titles published in over a hundred towns scattered around the archipelago. Most have never been microfilmed or digitized; a third exist only in this library. Once they have decayed to dust, these papers can never be recovered. Just at a time when a new historical awareness is dawning, the possibilities for rewriting Indonesia's history will be severely limited. Unless urgent action is undertaken now, future scholars will be deprived of perhaps the most vital link to the mid-twentieth century that they have.

I am not a librarian. I can only try to imagine how difficult it is to collect, organize, preserve and disseminate vital archival resources in a middle-income country like Indonesia that has many other priorities too. The librarian's difficulties are multiplied by the condition of most of these newspapers. These were printed on cheap paper in the midst of severe economic difficulties, and are now extremely fragile.

I am a historian, who uses libraries to learn about lives and societies of the past. The objective historian treats their sources with great care. This means being sceptical of them when necessary, being open to alternatives, fair to all the evidence and not just part of it, and honest when speculating about it. It means translating conscientiously from the sources, and considering the authenticity of "all" accounts and not just those they don't like. And it means looking for motives behind historical actions. ${ }^{1}$ No social scientist with historical interests and working on Indonesia can afford to ignore the accounts

1 These are (paraphrased and summarized) the criteria for the "objective historian" the judge adopted in his 2000 ruling dismissing Holocaust-denier David Irving's libel case against historian Deborah Lipstadt and her publisher, Penguin Books. The case was widely described as "history on trial", or, more accurately, "historical methodology on trial" (Schneider 2001). 
available in the masses of newspapers that have appeared in nearly every town, especially over the past hundred years.

We begin by examining a number of works of scholarship that have drawn extensively on newspaper archives, including those at the National Library. This is by no means a complete list. It merely serves to illustrate what is possible, how the results provide new perspectives on Indonesia's past, and what more their work inspires us to do in the future.

\section{SOME PIONEERING PROVINCIAL STUDIES}

The first is a study of West Sumatra in the 1950s, by Gusti Asnan (2007). This is an encouraging example with which to start, because it is mainly based on a newspaper, Haluan, that is safe. It exists in hardcopy in multiple libraries and has moreover been microfilmed. As Asnan read the pages of this Padang-based newspaper, a fascinating range of personalities came to life. They quite contradict the conventional image of provincial life as slow, traditional, and truculent. Besides the religious preachers, aristocrats, and soldiers that one expects to see in such a study, Asnan's book is peopled with women, students, young people, and some from outside the region. All are intensely politicized in those boisterous 1950s, full of optimism and open to the world. One of the most interesting personalities in his book is the aristocrat Datuk Bagindo Basa Nan Kuniang. The datuk started a local political party called the People's Customary Party (Partai Adat Rakyat). It combined an attachment to Minangkabau custom with a militant rejection of "colonialism, imperialism, and feudalism". It worked with the communist party PKI, and favoured a "collectivized" state-led economy. One of its top executives was a Batak Christian. None of this would be possible today; it happened in Padang in the 1950s.

In principle, Asnan's study could be reinterpreted by other historians after him, because the sources are still there. The same cannot be said of the book by Basilius Triharyanto (2009). This concerns a late colonial newspaper called Pertja Selatan. Palembang, the large city where it was published, first grew prosperous on colonial coffee, then on rubber. An educated indigenous middle class arose. All but forgotten today is the intensity of their political interests in the 1920s. Pertja Selatan was the local newspaper between 1926 and 1941. Not a single edition has been preserved in Palembang itself. Paper copies are preserved at the National Library. Only three years of the entire run has been microfilmed, and these editions are available also in other libraries around the world. The remainder are highly endangered. As Triharyanto turned the brittle pages in the library in Jakarta, a steady rain of fragments fell on the floor. A dust mask became necessary. Gradually a world opened up in those yellowing pages that was vibrant, optimistic, prosperous, and highly political. Subscriptions to Pertja Selatan were not cheap, but Palembang's "money people" (kaoem oeang) bought thousands of them. They knew Pertja Selatan as the Queen of the World (Ratoe Doenia). It was delivered to homes by "loopers", or sold loose in local bookshops. But it also travelled far out of 
town along the railway lines, bus lines, and even aerial routes that blanketed the archipelago by the late 1920s. People with some connection to Palembang ordered it from Borneo, Sulawesi, and even from as far away as Belgium, Egypt, Arabia, and the Soviet Union. The paper was run by an aristocratic family that had grown wealthy from coffee. It revelled in the anticolonial rhetoric of the nationalist movement. Its editors were particularly impressed with the communists, until the colonial authorities banned their organization in 1927. The tone was always feisty, abounding in allegations of treason against rival newspaper reporters. It once aired sexual abuse allegations against a Dutch official. The paper survived war and revolution. But the printer that published the Queen of the World finally went broke in 1962. Not much later, locals had forgotten the whole adventure. Triharyanto spent days searching for Pertja Selatan's editorial and printers offices. Vague hints eventually led him to an old building on the "wrong" side of the Musi River.

Next are two books on the Darul Islam rebellion of the 1950s and early 1960s. Darul Islam was by far the most significant internal conflict the republic has ever seen. ${ }^{2}$ Van Dijk's (1981) book was the first scholarly study on this episode, and it relied heavily on a wide range of local newspaper accounts. No other type of source would have been as good at revealing the sheer scope of the events, which ranged widely across the archipelago. Movements rose and fell at various times in West Java, Central Java, South Kalimantan, South Sulawesi, Aceh, and even in parts of Nusa Tenggara and Maluku. They were so diverse that it is fair to ask in what sense this was a single "rebellion". Van Dijk acknowledged this when he wrote in the preface:

The emphasis on and relative strength of the contributing factors varied from region to region. In Aceh, for instance, the rebellion combined religious inspiration with opposition to the increasingly pervasive influence of the Central Government. In South Sulawesi the demobilization of former guerillas after 1950 was decisive. In South Kalimantan the underestimation of local achievements in the struggle for independence figured prominently. In West and Central Java the Darul Islam rising was the result of a conflict over territorial autonomy, with strong Islamic overtones, sometimes mixed with millenarian beliefs.

Several of the newspapers that Van Dijk quotes most often are endangered. Two Banjarmasin papers exist only in the National Library in single copies of yellowing paper. They are Kalimantan Berdjuang (1949-1952, quoted 70 times), and Indonesia Berdjuang (1954-1955, quoted 75 times). (The latter was revived in the mid-1970s, and copies of that exist in several overseas libraries). Nusantara, published in Makassar 1950-1952 and quoted 61 times, seems to be only partly available at other libraries in microfilm form. Other newspapers he quoted appear to be safe. The Banjarmasin paper Indonesia Merdeka, the Jakarta daily Merdeka, and the Bandung paper Pikiran Rakjat, all for the 1950s and altogether quoted about 250 times, have been entirely microfilmed and are kept in other libraries too.

2 The killings of 1965 were a pogrom, not a two-sided conflict. 
The reader may respond at this point with a sense of relief that at least the Darul Islam rebellion was researched before the yellowing newspaper sources for its study had disintegrated completely. That would lessen the tragedy of them subsequently disappearing. However, such relief would be premature. A topic as huge as Darul Islam cannot possibly be described adequately in just one study. When the Italian historian Chiara Formichi in 2012 returned to the topic, she approached it with a completely different set of questions. It is as Santayana wrote (1905-06: Vol. 5, Ch. 2): "History is always written wrong, and so always needs to be rewritten". Whereas Van Dijk had seen the religious rhetoric deployed by Kartosuwiryo and other Darul Islam leaders as essentially political devices, Formichi wanted to be much more serious about the religion itself. Where Van Dijk had looked mainly at agrarian reforms and social struggles that were "justified" by religious language, Formichi wanted to write about a religious ideology that "motivated" the struggles. Old newspapers were only one of several kinds of sources she used, but the range of newspapers she did consult was even wider than Van Dijk's. Most have been microfilmed and appear safe. One could be endangered because it was microfilmed only partially. Kartosuwiryo wrote his first articles in the early editions of Fadjar Asia, published in Jakarta 1927-1930. Formichi quotes it 194 times! Yet only later editions seem to be microfilmed.

Another major study drawing on newspaper archives is Bill Frederick's (1989) dissertation on the social bases of the Revolution in Surabaya. This, too, reinterpreted an earlier reading of the revolution, namely Ben Anderson's (1972), written nearly two decades earlier. Anderson had depicted the youth (pemuda) as revolutionaries who led society "to free itself from the cycle of routine and regularity, and accept [...] the suspended soaring of the spirit" they represented (1972: 10). Frederick, by contrast, saw the pemuda as proteges of the younger aristocratic administrators (priyayi) who had matured under the late colonial regime. They were partly educated, and neither they nor the aristocrats wanted a general overturn of society. Together they formed the basis for a new indigenous middle class that came to dominate the city after independence. Frederick lists no fewer than 40 newspapers as his sources. Ten are not in the National Library at all - presumably he found them in and around Surabaya. Of those that are in Jakarta, a good number are safely microfilmed, while four are endangered. The latter are Bakti (published in Mojokerto, 1946-1947), Matahari (Semarang, 1932-1933), Pewarta Perniagaan (Surabaya, 1942-1943), and Soeara Rakjat (Mojokerto, 1946-1947).

Finally I may perhaps be permitted to mention my own study of the rise of an indigenous middle class in Kupang (Klinken 2014). I picked Kupang because there was nothing special about it. It was one of about 200 towns that today have populations of less than a million. These towns somehow hold Indonesia together by continually channelling flows of money, goods, ideas, and people to and from their surrounding rural areas. The indigenous middle class that runs Kupang town today was born in the period 1930s to 1980s.

Having chosen my study location, I discovered what a historical wasteland 
it was. Indeed, outside Java only Padang (see above) and Medan have newspaper archives for the 1950s available in Jakarta. And these are no longer towns but cities today. For the 1960s, not a single town or city outside Java has a surviving newspaper archive in Jakarta (though no doubt collections might still turn up in the provinces). For the 1930s the situation is slightly better. The colonial government required every newspaper publisher in the colony, no matter how small, to deposit a copy of every edition in Jakarta, or lose their licence. Those copies now make up the collection at the National Library. The same system exists today, but evidently it broke down in the chaotic years immediately after 1942. In the 1930s, little Kupang, population 7,000, had no fewer than nine regular if slim local Malay-language newspapers. They were funded by advertising from Chinese-owned shops. They told readers what they wanted to know - football matches, bicycle accidents, break-ins, sermons, visits by theatre troupes and high officials, insults in the market, the electricity supply, passing aerial adventurers en route to Sydney. But they also carried investigative reports on the economies of small towns on other islands, international news, and lots of local political intrigue.

Of these nine Kupang papers, none have survived completely. The survivors are all in the National Library, where all are endangered. They have never been microfilmed, and no other copies exist. They are (with their surviving years): Tjermin Timoer (1931-1932); Taman Masehi (1932); Oetoesan Timoer (1932-1934); Fadjar (1933-1934); Tjinta Kebenaran (1935-1938); Masehi Timoer (1935-1937); Obor Masjarakat (1938-1939); Pewarta Timoer (1940); and Soeara Timoer (1935-1936), the latter published by Timorese in Makassar. The paper on which these news broadsheets were printed was of poor quality. I recognize Triharyanto's story of a rain of fragments falling to the floor. In a few years' time no one will be able to read these newspapers any more. Many may be too badly damaged to read even now. Soon they will all be lost.

These studies all have the capacity to surprise us. They bring to light sources of political energy in places that are overlooked by scholars who focus only on national events. They break today's stereotypes about what kind of people provincials were in those dynamic and often chaotic years midtwentieth century. They invite us as researchers to look to the great unknowns in Indonesian history: problem periods like the 1950s, problem places like the provincial towns that remain largely terra incognita, and problem actors who do not fit the stereotypes (like Datuk Bagindo Basa Nan Kuniang). They invite debate and constant reassessment, such as that between Anderson and Frederick, or Van Dijk and Formichi.

The papers were vehicles for an up-and-coming generation of IndoEuropean and indigenous intellectuals. Reading them today, we sense that the social processes which provided a fertile soil for the disorders and uprisings of the revolution had been under way already for some time. The authority of the traditional elite had been undermined by its association with colonial rule; the established mechanism whereby rural society took care of its destitute members had been weakened by the commercialization of agriculture and 
the opening up of the interior; differences in wealth and land ownership had become more pronounced; and the mobile work force of the estates and the mining industry had increased in size. This is work for Indonesian historians, but also for historians from anywhere in the world who want to know how a new nation emerges among ordinary people. That makes the newspaper archives upon which all these studies rely not simply a regional or a national resource, but a resource for the whole world. The disaster that is now looming over them concerns everyone. So many more books still need to be written. But will they ever be written?

\section{THE JAKARTA COLLECTION}

On the seventh and eighth floors of a facility of Indonesia's National Library, on Jakarta's busy Jalan Salemba Raya, lies a national historical treasure. A total of 1,399 newspapers published in colonial and postcolonial Indonesia. The oldest one goes back to 1810 (the Java Government Gazette). It is the largest single collection of Indonesian newspapers in the world. Nearly every city in Indonesia at some time published its own local newspaper in bahasa Melayu/ bahasa Indonesia. Some collapsed after a few editions, others ran for decades. Each one of them is a priceless source of information about daily life in that region.

To arrive at an estimate of the state of the newspaper archives held at the National Library, my colleagues and I began with the catalogue published by Wartini Santoso (1984). The Santoso catalogue was in turn based on the somewhat less complete catalogue by Mastini Hardjoprakoso (1977). However, we have no illusions these catalogues accurately represent today's available collection. A lot could have happened over the three and a half decades since Santoso's publication. I am not aware of any major new historical newspaper acquisitions at the library since then. On the contrary, it seems likely that not everything in Santoso is actually still in the Library. When the new building at Jalan Salemba Raya 28A was completed some time after Santoso's catalogue was published, the entire collection was moved. Anecdotes are told of possibly irreparable damage being inflicted on some archives during the moving operation. Since then the main library facilities have moved again, to Jalan Medan Merdeka Selatan 11. The paper newspaper archive remains for now at Jalan Salemba Raya. If the collection is moved again, extreme care will have to be taken to ensure no further damage ensues. In the meantime, users have long noticed that the number of library staff assigned to guard and make accessible this priceless collection has always been small. This unfortunately increases the likelihood that everyday misadventures have occurred over the years: misplacement, vandalism, and deterioration through handling fragile paper.

My colleagues Esrih Bakker and Joes de Natris, working at the KITLV under a work experience program, first transferred every entry from Santoso into an Excel spreadsheet. This permitted them to make some basic plots about the places where they came from and the years in which they were published.

The list of cities and towns in which newspapers were published that are 
now kept at the National Library has 112 names. Most of these - 103 places have at least one endangered historical newspaper (only microfilm outside the National Library hardcopy) or one highly endangered newspaper (no copy outside the National Library) (see Table of cities in Appendix 2). Besides the big cities of Medan, Jakarta, and Makassar, the table contains numerous ordinary provincial cities, from Ambon to Yogyakarta. Of these, newspapers from 60 towns are "highly" endangered, meaning there is no copy of any kind outside the National Library. I happen to know that "all" the historical newspapers for Kupang are endangered. And I fear Kupang is not alone.

How many of these 103 places with endangered archives do not yet have a serious historical study that uses these newspapers? I have not made a systematic survey of provincial histories, but my guess is the number is very high. Even those few towns for which we do have a study are not out of danger, for Santayana says restudies are essential to good history-writing. Non-specialized historians have not even begun to realize what they can do with these archives. Linguists can see regional dialects developing over time in these pages; cultural anthropologists can observe clothing fashions sweep over an Asian society; economists can study the local impacts of global capitalist crises; agricultural scientists can see new plantation economies rise and fall; political scientists can observe a revolution; and urban sociologists can plot urbanism coming to a huge rural developing country.

Which period is best illuminated by the newspaper archives in the National Library? The graph shows that most of the newspapers in the National Library are in Indonesian (or Malay), with a few in Javanese, Dutch, and other languages (see Appendix 1). Most date from the late colonial period, peaking in the 1920s and 1930s. This reflects the rise of an educated indigenous middle class in this period, as described in the histories of Sutherland (1979) and Van Niel (1960). Many were young aristocratic administrators (priyayi) in the colonial bureaucracy. But a number date back to the nineteenth century. Ricklefs (2007) read them to paint a picture of a tiny literate elite in Java whose intellectual horizons were exploding until they embraced the whole world. Yet even some of these papers are highly endangered. Neither Soerat Kabar Bahasa Melajoe (Surabaya, 1856) nor Tjahaja Moelia (Surabaya, 1883) appear to have any copies outside the National Library. And the library also has a large number of postcolonial newspapers. Among them is the famous Muslim reformist daily Abadi (Jakarta, 1954-1969). Abadi is a highly endangered newspaper.

How did we determine which of these newspapers are endangered? Once Bakker and De Natris had digitized the Santoso catalogue, they searched on each entry at www.worldcat.org. They noted down other holdings elsewhere in the world, either in hardcopy or microfilm/microfiche. Most of those they found turned out to be held by a small number of major, well-known collections such as KITLV in Leiden, the National Library of Australia, Cornell University, the American Library of Congress, or the School of Oriental and African Studies in London. We then were able to detect those titles that are most endangered. These are those of which probably only one copy in the 
world exists - there on the seventh and eighth floors on Jalan Salemba Raya and for which no microfilm has ever been made. ${ }^{3}$ The number comes to one third of the full collection: 458 titles. This is likely to be an under-estimate, for two reasons. First, if WorldCat says a hardcopy exists in another library, that does not necessarily mean a full run exists there. Often only a single copy is kept overseas, where the National Library has a collection spanning years. Second, those that were microfilmed are not necessarily out of danger. Many microfilms and microfiches were made in the 1970s, under a rushed program with sub-optimal equipment. The plastics used then have often deteriorated as well. We were unable to verify the condition of the film.

In short, while these 458 are the most highly endangered newspapers in Indonesia's historical collection, this does not mean the remaining two thirds is safe. In only 189 cases can the paper be regarded as out of harm's way. Haluan, published in Padang 1951-1957 and discussed above, has been microfilmed and also exists in paper form at the National Library of Australia. For the vast majority - 1,135 to be precise - no paper copy exists anywhere else in the world as far as we know. It is no exaggeration to say that all those 1,135 newspapers are endangered.

\section{WHAT CAN BE DONE?}

Disaster can be avoided if action is taken now. A massive digitization program will both conserve the content of these newspapers, and add immeasurably to their value to researchers. Unlike microfilm, digital data does not deteriorate (provided the storage medium is constantly monitored and periodically refreshed). Even more importantly, they can be searched automatically. Digitized newspapers will make possible a revolution in Indonesian social science research. The process takes place in two phases. In the first, conservation, every page of every newspaper is scanned electronically. This electronic image archive is stored securely so it can never be lost, and so it can be reprocessed in the future if necessary. In the second phase, archival opening, those pages are turned into digital text by means of Optical Character Recognition software (OCR), and then disaggregated into discrete articles, with metadata for each article. It must then be disseminated by being placed online (not merely on CD-ROM) for the widest possible access.

The result can be searched and read electronically by researchers anywhere in Indonesia and abroad. Similar programs, such as the marvellous Delpher portal in the Netherlands (www.delpher.nl), have opened up entirely new possibilities for research. Even the simplest searches can automatically scan millions of newspaper articles covering a period of decades in different localities around the country. Looking for names can assist biographers of wellknown individuals. This has proven popular among people researching family genealogies elsewhere. Looking for unusual expressions can show linguists when and by whom it was first used. Indeed, an online digital newspaper

3 I will be happy to supply the resulting spreadsheet to any interested reader free of charge. 
archive is today considered essential not only by historians but by all kinds of scholars, from linguists to economists, lawyers to anthropologists, medical scientists to agriculturalists. More complex "digital humanities" research programs deploy techniques such as complex network analysis, sentiment analysis, and topic modelling. When combined, these can support research into social, cultural and political movements, ranging from the introduction of American consumer items to the complexities of the Indonesian Revolution.

Digitization remains fairly expensive, but it has become quite routine in today's world and financially no longer beyond the reach of a middle income country like Indonesia. There are international programs such as The Endangered Archives program at the British Library, which also operates in Indonesia. The digital archiving organization JSTOR also has an interest in conserving endangered printed media. However, Indonesia is no longer a poor country, and I have little doubt it could manage this important conservation, opening and dissemination project with its own resources. The national budget for research and education has expanded enormously in recent years. Most cities and districts, moreover, have budgets for preserving their local history. If each district listed in the Table contributed a small amount towards the costs, they would each gain a treasure trove of easily accessible newspaper data.

Perhaps the reason why the endangered newspaper archives at the National Library of Indonesia have not yet been digitized are more political than financial. Social scientists have a substantial voice in Indonesian civil society. Wouldn't it be nice if academics were to initiate a strong, urgent proposal to digitize the national newspaper archive? Together with local governments, national politicians, and library administrators they could build a very strong case to make this a national priority. Historians are perhaps best placed to take the initiative. Enrolments at university history departments are up around the country. Most universities now also have international collaborations that give them added resources to mobilize. A rising interest in local history, combined with Indonesia's current economic prosperity, makes this a good moment to launch a "digitize my heritage" movement. If Indonesians around the country, from Demak to Tarutung, from Kupang to Tulungagung, take action now, they can save the nation's historical memory at the National Library of Indonesia for future generations. They should ask that the digitized newspapers be made publicly available online, for anyone to search and quote. They should say to the public: "Imagine being able to search on your grandfather's name in Abadi, published in Jakarta between 1954-1969!" If Indonesian academics do not take up this issue now, it will be too late. 


\section{REFERENCES}

Anderson, Benedict R. O'G. 1972. Java in a time of revolution; Occupation and resistance 1944-1946. Ithaca, NY: Cornell University Press.

Asnan, Gusti. 2007. Memikir ulang regionalisme; Sumatera Barat tahun 1950-an. Jakarta: Yayasan Pustaka Obor Indonesia.

Dijk, Cees van. 1981. Rebellion under the banner of Islam; The Darul Islam in Indonesia. The Hague: Martinus Nijhoff. [KITLV Verhandelingen 94.]

Frederick, William H. 1989. Pandangan dan gejolak; Masyarakat kota dan lahirnya Revolusi Indonesia (Surabaya 1926-1946). Jakarta: Gramedia and Yayasan Karti Sarana.

Hardjoprakoso, Mastini. 1977. Koleksi surat kabar Perpustakaan Museum Pusat 1810-1977. Jakarta: Perpustakaan Museum Pusat.

Klinken, Gerry van. 2014. The making of Middle Indonesia; Middle classes in Kupang town, 1930s-1980s, power and place in Southeast Asia. Leiden: Brill.

Niel, Robert van. 1960. The emergence of the modern Indonesian elite. The Hague: Van Hoeve.

Ricklefs, M. C. 2007. Polarising Javanese society; Islamic and other visions, c. 18301930. Leiden: KITLV Press.

Santayana, George. 1905-06. The life of reason; The phases of human progress. 5 vols. New York: Dover.

Santoso, Wartini (ed.). 1984. Katalogus surat kabar 1810-1984. Jakarta: Perpustakaan Nasional.

Schneider, Wendie Ellen. 2001. "Past imperfect; Irving v. Penguin Books Ltd., No. 1996-I-1113, 2000 WL 362478 (Q. B. Apr. 11), appeal denied (Dec. 18, 2000)", The Yale Law Journal 110 (8): 1531-1545. [DOI: 10.2307/797584.]

Sutherland, Heather. 1979. The making of a bureaucratic elite; The colonial transformation of the Javanese priyayi. Singapore: Heinemann.

Triharyanto, Basilius. 2009. Pers perlawanan; Politik wacana antikolonialisme Pertja Selatan. Yogyakarta: LKIS. 


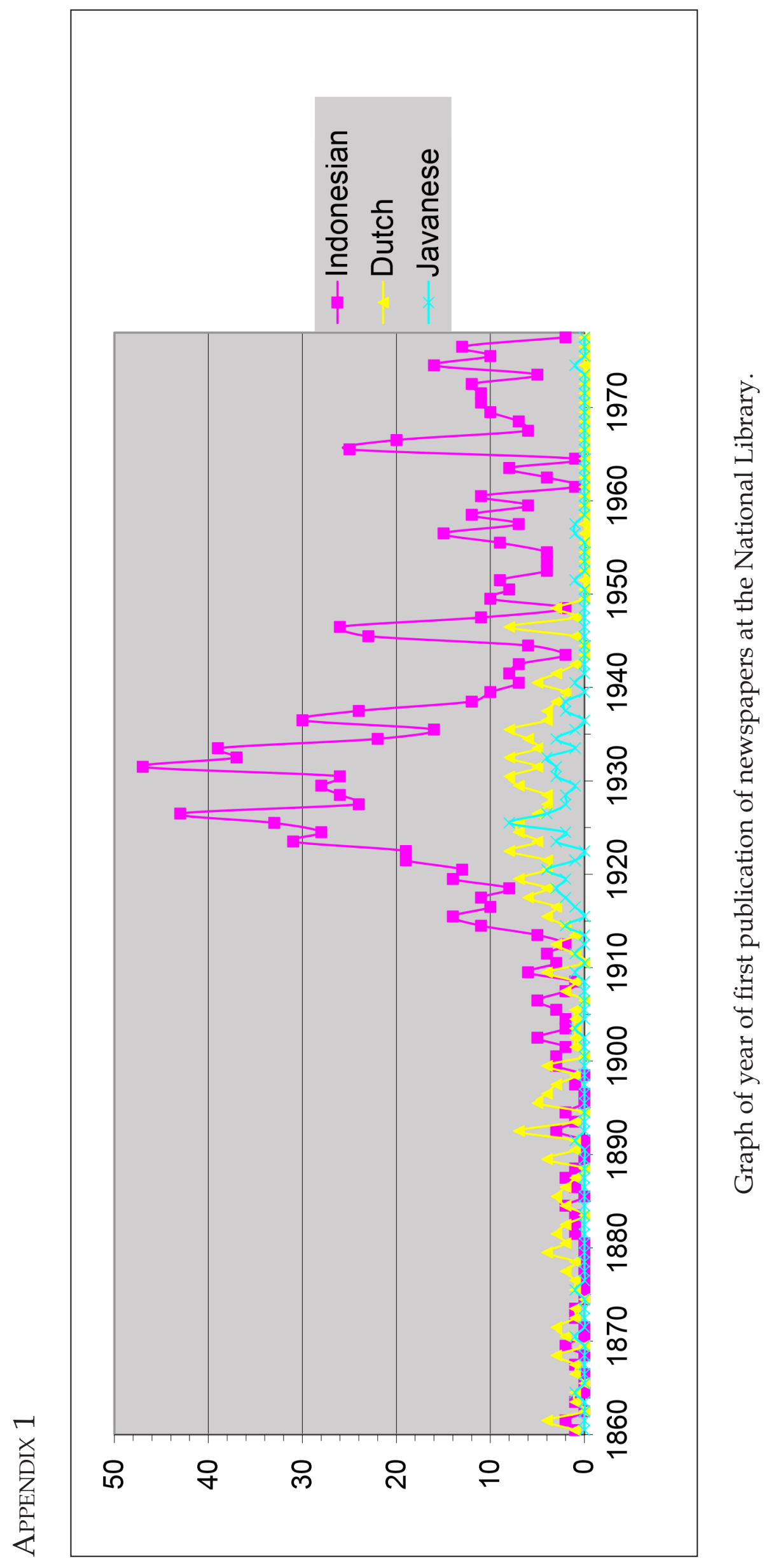


APPENDIX 2:

Table of cities in which newspapers were published that are endangered.

\begin{tabular}{|c|c|c|c|c|}
\hline Ambon & Cimahi & Langsa & $\begin{array}{l}\text { Payakumbuh } \\
\text { (West } \\
\text { Sumatra) }\end{array}$ & Sukabumi \\
\hline Amurang & Cirebon & $\begin{array}{l}\text { Lintau } \\
\text { p/a Parak } \\
\text { Juar (West } \\
\text { Sumatra) }\end{array}$ & Pekalongan & $\begin{array}{l}\text { Sukaraja } \\
\text { (Central Java) }\end{array}$ \\
\hline $\begin{array}{l}\text { Balige- } \\
\text { Tampahan } \\
\text { (Tapanuli) }\end{array}$ & Demak & Madiun & $\begin{array}{l}\text { Pematang } \\
\text { Siantar }\end{array}$ & Sungailiat \\
\hline Balikpapan & Denpasar & Magelang & Pontianak & Surabaya \\
\hline $\begin{array}{l}\text { Banda Aceh/ } \\
\text { Kutaraja }\end{array}$ & Garut & Magetan & Probolinggo & $\begin{array}{l}\text { Surakarta/ } \\
\text { Solo }\end{array}$ \\
\hline Bandung & Gorontalo & $\begin{array}{l}\text { Makassar/ } \\
\text { Ujung } \\
\text { Pandang }\end{array}$ & Purwakarta & $\begin{array}{l}\text { Tanjung } \\
\text { Balai (Eastern } \\
\text { Sumatra) }\end{array}$ \\
\hline Banjarmasin & Gresik & Malang & Purwokerto & $\begin{array}{l}\text { Tanjung } \\
\text { Karang } \\
\end{array}$ \\
\hline $\begin{array}{l}\text { Banyumas } \\
\text { (Central Java) }\end{array}$ & Gunung Sitoli & Mataram & $\begin{array}{l}\text { Purworejo/ } \\
\text { Klampok }\end{array}$ & Tarutung \\
\hline $\begin{array}{l}\text { Beji-Pedan } \\
\text { (Central Java) }\end{array}$ & $\begin{array}{l}\text { Jakarta/ } \\
\text { Batavia/ } \\
\text { Weltevreden/ } \\
\text { Jatinegara/ } \\
\text { Meester } \\
\text { Cornelis } \\
\end{array}$ & Medan/ Binjei & Rangkasbitung & Tasikmalaya \\
\hline $\begin{array}{l}\text { Belinyu } \\
\text { (Bangka } \\
\text { Island) } \\
\end{array}$ & Jayapura & $\begin{array}{l}\text { Menado/ } \\
\text { Lawangirung/ } \\
\text { Langoan }\end{array}$ & Salatiga & Tebing Tinggi \\
\hline $\begin{array}{l}\text { Bengkulu/ } \\
\text { Curup }\end{array}$ & Jember & Mojokerto & Samarinda & Tegal \\
\hline Blitar & Jombang & Muntilan & Sampang & Teluk Betung \\
\hline Bogor & Kabanjahe & Padang & $\begin{array}{l}\text { Sawahlunto/ } \\
\text { Talawi (West } \\
\text { Sumatra) }\end{array}$ & Ternate \\
\hline $\begin{array}{l}\text { Bogor/ } \\
\text { Buitenzorg }\end{array}$ & $\begin{array}{l}\text { Kayutanam } \\
\text { (West } \\
\text { Sumatra) }\end{array}$ & $\begin{array}{l}\text { Padang } \\
\text { Panjang }\end{array}$ & Semarang & Tilatang \\
\hline Boyolali & Kediri & $\begin{array}{l}\text { Padang } \\
\text { Sidempuan }\end{array}$ & Serang & Tomohon \\
\hline Brebes/ Jati & Klaten & Palembang & Sibolga & Tondano \\
\hline
\end{tabular}




\begin{tabular}{|l|l|l|l|l|}
\hline $\begin{array}{l}\text { Bukittinggi/ } \\
\text { Fort de Kock }\end{array}$ & Kotamabagu & Palu/ Dolo & $\begin{array}{l}\text { Sidikalung } \\
\text { (Tapanuli) }\end{array}$ & Tulungagung \\
\hline Cepu & Kudus & Pamekasan & Sigli & Wonosobo \\
\hline Ciamis & Kupang & $\begin{array}{l}\text { Pangkal } \\
\text { Pinang } \\
\text { (Bangka) }\end{array}$ & Sipirok & $\begin{array}{l}\text { Yogyakarta/ } \\
\text { Kota-gede/ } \\
\text { Mataram/ } \\
\text { Pasargede/ } \\
\text { Wates }\end{array}$ \\
\hline Cianjur & Kutoarjo & $\begin{array}{l}\text { Pariaman } \\
\text { (West } \\
\text { Sumatra) }\end{array}$ & $\begin{array}{l}\text { Siporak } \\
\text { (Tapanuli) }\end{array}$ & \\
\hline Cilacap & Lampung & Pasuruan & $\begin{array}{l}\text { Solo/ } \\
\text { Kauman-Solo }\end{array}$ & \\
\hline
\end{tabular}

